149 Main Street, South Glens Falls, NY 12801; Ann Woodward, 834 Oakdale Road, N.E., Atlanta, GA 30307; Donald C. Earnshaw, 226 South Douglas, Lee's Summit, MO 64063; ACRL Representatives; Chairman: Anne C. Edmonds, Librarian, Mount Holyoke College, South Hadley, MA 01075; Darrell H. Lemke, Coordinator of Library Programs, Consortium of Universities, 1717 Massachusetts Ave., N.W., Washington, D.C. 20036; Hal C. Stone, Coordinator, Library and Learning Resources Center, Los Angeles City College, Los Angeles, CA 90029 .

NUEA/ACRL Joint Committee on University Extension Library Services. ACRL Representatives: Karl S. Bynoe, Humanities Librarian, Mugan Memorial Library, Boston University, Boston, MA 02215 (1972/74); Nina T. Cohen, Director, Western New York Library Resources Council, Lafayette Square, Buffalo, NY 14203 (1972/74); Dorothy A. Kittle, Library Extension Specialist, U.S. Office of Education, Division of Library Services and Educational Facilities, Washington, DC 20202 $(1970 / 73) ; 1$ to be appointed; NUEA Repre- sentatives; Chairman: to be appointed; Martin N. Chamberlain, Director, University Extension, University of California at San Diego, La Jolla, CA 92037 (1971/73); Alfred L. Harding, Director, Division of Extended Services, Indiana State University, Terre Haute, IN 47809 (1971/73); Ralph E. Nelson, Provost, Off-Campus Education, West Virginia University, Morgantown, WV 26506 (1971/73).

\section{REPRESENTATIVES}

ACRL Representative to the American Association for the Advancement of Science. William S. Budington, Executive Director and Librarian, The John Crerar Library, 35 West 33rd St., Chicago, IL 60616 (1971/74).

ACRL Representative to the American Council on Education. Donald C. Anthony, Associate Director of Libraries, Columbia University Libraries, New York, NY 10027 (1972/74).

ACRL Representative to the ALA Membership Promotion Task Force. Mary Louise B. Cobb, Head, Cataloging Department, Earl Gregg Swem Library, College of William and Mary, Williambsurg, VA $23185 \quad(1972 / 74)$.

\title{
Librarians Challenge
}

\section{"Harmful Matter Statute"}

On May 5, 1972, library history was made by the filing in federal court of a class action suit-funded by the Freedom to Read Foundation-on behalf of all California librarians and library employees. This legal action marks the first time that librarians, themselves, have taken the offensive and have sought legal precedent for the Library Bill of Rights. The suit challenges the constitutionality of the state "Harmful Matter Statute" which makes librarians subject to prosecution for distributing to minors any publications deemed "harmful matter" under the definition set down in the statute.

Filed in the U.S. District Court for the Southern District of California, the civil action asks for an injunction restraining the California State Attorney General from prosecuting library employees under the Harmful Matter Statute. The suit also seeks a judgment declaring the statute to be unconstitutional because it acts as a prior restraint on the First Amendment rights of library employees and the public they serve, and is void for vagueness and overbreadth as applied to library employees.

The California Harmful Matter Statute became effective on Nov. 10, 1969. For a first offense, it provides for penalties of up to $\$ 2,000.00$ in fines and/or up to a one-year prison term for the "distribution" to a minor of any matter deemed "harmful." Subsequent offenses are felonies and carry more severe penalties.

That the statute applies to librarians was made clear in statements by Roger Arnebergh, Los Angeles City Attorney and Brian Crahan, Los Angeles Deputy City Attorney, and in an opinion rendered by the Office of the Attorney General on January 21, 1972. Based on these clearly articulated threats of prosecution, the Freedom to Read Foundation concluded that the statute imposes serious and irreparable injury for library employees.

The complaint declares that:

As librarians are not qualified either by training or experience to act as censors, and since the inevitable tendency is to err on the side of caution, the public's access to the entire range of legal reading materials is unnecessarily curtailed. . . The obligation that the statute seeks to impose on plaintiffs and members of the class constitutes an unconstitutional form of prior restraint. In order to comply with the statute, members of the plaintiff class are required to engage in a form of censorship and make an evaluation as to whether any given work constitutes "harmful matter" and, if so, prohibit a minor from borrowing 
or reading such work ... a procedure which cannot be constitutionally imposed on the plaintiffs.

The plaintiffs in this landmark action are: Everett T. Moore, Albert C. Lake, Robert E. Muller, Chase Dane, the Rev. Charles J. Dollen, Anita Iceman, the American Library Association, the California Library Association, and the Los Angeles Public Library Staff Association. Together, the individual and organizational plaintiffs represent a broad spectrum of library employees in the State of California. Moore is assistant librarian at the University of California at Los Angeles; Lake is the director of the Riverside Public Library and the Riverside County Free Library; Muller is the Director of Instructional Materials of the Jefferson Elementary School District located in Daly City; Dane is the Director of Libraries and Instructional Services of the Santa Monica Unified School District; the Rev. Charles J. Dollen is the Director of the Knights of Columbus Memorial Library of the University of San Diego; Ms. Iceman is the Coordinator of Young Adults Services of the Alameda County Library.

A copy of the complaint filed in U.S. District Court for the Southern District of California is available from the Freedom to Read Foundation, 50 E. Huron St., Chicago, IL 60611.

\section{SCMAI SUBCOMMITTEE REPORT}

\section{Doiron Request for Action}

After studying more than 250 documents, 29 transcripts of 30 interviews, and 18 responses from other individuals, the fact-finding subcommittee appointed by the Staff Committee on Mediation, Arbitration and Inquiry (SCMAI) to gather the facts relating to Peter M. Doiron's Request for Action, has submitted its report to the American Library Association's Executive Board. Doiron submitted a Request for Action to the SCMAI in accordance with the procedures of the Program of Action for Mediation, Arbitration and Inquiry, on January 11, 1972. In his Request for Action, Doiron asked that the SCMAI make an inquiry of his dismissal as editor of CHOICE, a review journal administered by the Association of College and Research Libraries (ACRL), on July 29, 1971.

Doiron, in his Request for Action, stated that he considered the problem to be (1) a lack of due process; (2) unethical behavior; (3) intellectual freedom; (4) unfair employment practices; and (5) tenure. Doiron alleges that he had no prior warning of his termination nor had any of the ACRL officers.

The subcommittee concluded that the American Library Association denied Doiron formal due process. This denial resulted from the ALA's failure to utilize its formal, prescribed personnel performance procedures with Doiron during the course of his employment as an ALA staff member. As a consequence of this failure, Doiron was deprived of the opportunity to appeal an unsatisfactory performance evaluation.

Among the other conclusions reached by the fact-finding subcommittee was that there was no evidence of unethical action, although the details of the manner in which the dismissal was conducted displayed a lack of sensitivity and professionalism. In regard to Doiron's allegations of violations of the principles of intellectual freedom, the fact-finding subcommittee found that at no time was there any indication or charge that the editorial content of CHOICE magazine was under pressure or compromised.

Further, except for the lack of formal due process noted above, there was no evidence of unfair employment practices on the part of the ALA administration. The fact-finding subcommittee stated that "Doiron had been adequately warned and the executive director had full authority to dismiss him."

The subcommittee also established that in accordance with ALA personnel policies, Doiron was not a tenured employee at the time of his dismissal in July of 1971 and therefore, was not entitled to the protections of tenure.

Finally, the fact-finding subcommittee concluded that it was formed in response to Doiron's Request for Action seeking a resolution of his appeal of the method used in his dismissal. Recognizing that the procedures of the factfinding inquiry do not allow all principals to be present during all the interviews and cannot, thus, be construed as constituting a hearing, the subcommittee determined that it would be inappropriate for it to rule on Doiron's request for "restoration" to the post of editor or upon the resolution of his appeal.

Based on its findings and conclusions, the fact-finding subcommittee recommended as follows:

1. That the ALA Executive Board grant to Peter M. Doiron a formal hearing.

2. That this hearing be conducted by a team of executive board members with a complete report of findings and recommendations made to the full board for its decision.

3. That the hearing be conducted in accordance with the principles of the Statement on Procedural Standards and Faculty Dismissal Proceedings of the American Asso- 